\title{
The Phenomenology Study of Phenomenology: Experience of Self-Caring of Leprosy Patients in the Central Medicine and Disabled St. Damian Cancar, Manggarai
}

\author{
Maria Getrida Simon ${ }^{1}$, Lidwina Dewiyanti $\mathrm{Wea}^{2}$, and Lusia Henny Mariaty ${ }^{3}$ \\ \{riasimon0307@gmail.com\} \\ Unika Santu Paulus Ruteng ${ }^{123}$
}

\begin{abstract}
Leprosy is one of infectious diseases that causes very complex problems, not only in medically context but also to social, economic, cultural and security context. Leprosy is commonly found in developing countries as a result of the country's limited ability to provide health and education services to the community to reduce the level of disability. The aim of this study is to collected data about the experience of leprosy patient to do self-care. The qualitative study was used to identify the themes related to the leprosy patient experience about self-care. Data were collected by interview recorder with voice recorder. There were 4 themes obtained in this study. First theme was the consume drugs, these themes were developed because the majority of the respondent said with consume drugs make the disease improve, the second theme consume nutritious food, the participant said with the nutritious food increase the immune body, the third theme was submerged, the majority of participant always do the submerge to repair the skin, the last them was rubbing with $\mathrm{VCO}$, some of respondent said after submerge they continue with the rubbing the skin used VCO. Based on the result of study, the majority of the participant was do the self-care to prevent the disability, the result of this study to inform the self-care of leprosy, this disease in one of the neglected diseases but we still should to know because maybe around us this disease still exist.
\end{abstract}

Keywords: Self-care, Experience, Leprosy, Phenomenology study

\section{Introduction}

Leprosy is one of infectious diseases that causes very complex problems, not only in medically context but also to social, economic, cultural and security context. Leprosy is commonly found in developing countries as a result of the country's limited ability to provide health and education services to the community to reduce the level of disability.1 Leprosy is a contagious, chronic disease caused by leprosy germs, Mycobacterium leprae, which mainly attacks the peripheral nerves, and in turn can attack the skin and other body tissues, such as the oral mucosa, upper respiratory tract, reticuloendothelial system, eyes, muscles, bones, and testes, except the central nervous system.2

Nerve infection is an integral part of leprosy, but permanent nerve damage that causes disability does not always have to occur in lepers. Disability is often experienced by many leprosy clients before getting treatment because of the weak knowledge and awareness of clients, families, and even the community of leprosy.2. As a result, there will be a fundamental 
change in the personality and behavior of the patient, the patient tries to hide his condition as a leprosy client. This does not support the process of treatment and healing, on the contrary will increase the risk of disability. Disability in people affected by leprosy is still stigmatizing in the community, so people with leprosy are difficult to accept even though the disease has been declared cured. The aim of this study to seek the experience of self-care leprosy patient 3 .

The World Health Organization (WHO)41 reported in 2016 that the discovery of new leprosy cases was obtained from 106 countries in 5 WHO regions as many as 210,758 cases in 2015. Indonesia ranks third with the highest prevalence (incidence) of leprosy after India and Brazil. The most prevalence of leprosy is India with an incidence of 127,326 cases, Brazil with 26,395 cases, and Indonesia with leprosy incidence as many as 17,202 cases

According to a report from the Directorate General of Disease Control and Prevention (DG P2P), the Ministry of Health of the Republic of Indonesia (2017) in the Indonesian Health Profile, Ministry of Health of Indonesia (2016)52, said that there were 20,748 cases of leprosy, including 2,374 Paucibacilliar (PB) patients' cases, while Multibacilliar (MB) were 18,374 cases, where this number was only temporary because not all Provinces submitted their final reports. In 2016, the Indonesian Ministry of Health reported that of the 34 Provinces in Indonesia, East Java Province ranked first with leprosy cases as many as 4,668 cases ranked second in West Java Province with 2,410 cases and East Nusa Tenggara (NTT) ranked eighth with leprosy cases of 647 cases, including PB 61 cases and MB 586 cases where the lowest number of cases of leprosy cases was in Riau Islands Province with 29 cases.

Leprosy often causes dryness of the skin due to nerve damage. One of the damaged nerves is the nerve that controls dryness, which causes the patient's skin to become dry. Self-care is an act of maintaining one's hygiene and health for physical and psychological well-being (Potter, 2005)53. With good self-care, it can prevent nerve damage that can increase disability in leprosy patients. The conditions that often appear in leprosy patients are skin cracks in the folds of the hands, around the heels and folds between the toes. This cracked skin is skin that should not be ignored, if not treated it will become a window of infection in leprosy patients2. According to Hartanti, showed that a courding to research by Hartanti , (2015)6 shows that most patients do not do self-care, with the excuse of being lazy and a lot of busyness that takes up time and forgets to do self-care, while those who do self-care believe that routine care will reduce the risk of more severe disability.

Based on the review above, the researchers are interested in conducting research on the experiences of leprosy patients doing self-care in the Central Medicine and Disabled st. Damian Cancar, Manggarai

\section{Methodology}

This study uses a qualitative study as a research method with a phenomenological approach. Data were collected using semi-structured interview method with the aim of exploring the experiences of leprosy patients in self-care. The sample in this study was selected based on purposive sampling technique with the following criteria: 1 . Willing to be a respondent 2.16 years to 55 years old 3 . Has recovered or is an active person with leprosy 4 . Be present at the time of the research. The data saturation in this study was obtained from the 6th informant so that the informants in this study were 6 people.

Tools used to collect data for research: 1 . Interview guide: the researcher prepares a list of interview questions. Before starting the interview, participants were asked to fill out a consent 
form. 2. Recorder: participants' answers are recorded with the help of a recording device provided. The data of all participants were organized according to the order of the interview items followed by analysis using the thematic analysis method.

Initially, the participants were explained about the purpose of the study and the identity of the participants was kept secret. The sample in this study was determined based on inclusion criteria. Participants in this study are those who are willing to participate voluntarily. When collecting data, participants feel as comfortable as possible when being interviewed. The data that has been collected is then analyzed.

\section{Result and Discussion}

\subsection{Result}

After conducting a thematic analysis of the self-care experiences of leprosy patients, the following themes were obtained:

\section{Consume drugs}

This theme emerged from the participants' admission of their discipline in consuming leprosy medicine, reflected in the expression "I have been taking leprosy for 7 months and always drank at 5 am". days"., "After I was diagnosed with leprosy, I was obliged to take 2 types of drugs for 1 year." More or less, I always took the same medicine for 1 year. Regularly taking medication can speed up the healing of leprosy and reduce the number of disabilities.

\section{Eat nutritious foods}

Most of the participants said that in addition to taking drugs, one of the things they should do for self-care is to always consume nutritious food. This theme is illustrated in the phrase "the nurse advised me to always eat nutritious food to fight the leprosy"., "Nutritious food is one thing that must be consumed to treat this leprosy." Nutritious food is very good for boosting the body's immune system so that it can fight microorganisms that cause leprosy

\section{Soak}

From the results of interviews with respondents, it was found that the third theme was doing foot or hand soaking for more than 1 hour. This theme is derived from the statement of the respondent: "I usually soak my feet and hands in water mixed with salt." I always soak my feet twice a day in cold water. "Every day I soak the thickened skin.". Soaking the feet and hands affected by leprosy can help reduce the thickness of the skin, thereby reducing the level of disability

\section{Applying VCO oil}

This theme was obtained from the results of interviews with participants through the phrase "after taking a shower I rub the numb parts of the skin with virgin coconut oil." Because there is a lot of virgin coconut oil at home so after taking a shower, I always rub it on my elbows and face which is black. I always rub virgin coconut oil on my feet to avoid chapping". Rubbing with VCO on the part of the body that has lost sensation can help healing. 


\section{Discussion}

Based on the results of the study, it shows that the participants have carried out self-care in accordance with government recommendations regarding self-care for leprosy patients. From the results of the quantitative data analysis carried out, there are 4 themes that arise regarding the self-care experience of leprosy patients. From the results of the study, it appears that respondents already know how-to do-good self-care, although there are some patients who feel that they should not experience this disease because they feel that people always maintain cleanliness and that their house conditions are clean and bright. The Directorate General of PP \& PL, Ministry of Health, 2014 stated that the hotter the weather, the faster the leprosy germs will die, in this case the sunlight that enters the house is very important, because leprosy germs will develop in a valley where it rarely gets sunlight. Self-care is the act of maintaining one's cleanliness and health for both physical and psychological well-being (Isro'in \& Andarmoyo, 2012) 85 .

The results showed that the respondents had carried out self-care for leprosy well, so that it could heal and experience changes from time to time. This can be seen from the statement I feel a lot of changes after taking regular medication. In general, self-care aims to maintain selfhealth independently and help. Self-care trains a person to live a healthy life by improving the view of health and hygiene, and shaping behavior and appearance that is in accordance with health (Alimul, 2014)96.

According to Tarwanto and Wartonoh (2015)107, self-care also aims to improve one's health, can prevent disease, increase self-confidence and self-actualization, and shape beauty. According to one respondent when he was diagnosed with leprosy, he was very embarrassed and tried to keep his illness a secret so that his friends would not avoid him, but with self-care that was carried out and experienced changes, he slowly increased his self-confidence. Treatment of dry and cracked skin can be done by soaking the feet or hands for 20 minutes every day, rubbing the thick skin then rubbing with vaseline or cooking oil regularly to keep the skin moist (Tarwanto and Wartonoh, 2015)107. This is similar to several themes raised by several respondents.

According to research conducted by Faruq Umar (2018)118, it shows that the level of disability has nothing to do with self-care, but according to researchers, poor self-care will cause leprosy patients to experience disabilities and lead to decreased quality of life. According to Potter \& Pery (2005)53, there are several factors that can affect a person's self-care, including body image, level of knowledge and physical condition. Mahanani (2013)129 in a study states that self-care for clients with leprosy can be influenced by age, education level, income, family roles, and the role of health workers. Health workers have a big role to play in self-care. Health workers through health promotion can increase awareness of clients with leprosy to always carry out self-care. At the end of the interview, the respondents were grateful because they received health services and were always given education and were taught how to take good care to prevent disability from occurring.

\section{Conclusion}

There are 4 themes that emerge in this research, namely regularly taking medication, consuming nutritious foods, soaking and scrubbing with VCO oil. This study aims to obtain a description of the experience of leprosy patients in self-care. The themes identified illustrate 
that the self-care carried out by leprosy patients has been done as well as possible in order to reduce disability as a result of this leprosy disease. The results of this study are expected to be a source of information for leprosy patients, considering that leprosy is now a neglected disease but it does not rule out leprosy around us. For further research, researchers suggest that they be able to conduct a quiet? study of the quality of life of leprosy patients with more specific sample criteria.

\section{Acknowledgement}

Thanks to all humble people at Central Medicine and Disabled St. Damian Cancar, Manggarai for agreeing to be interviewed and giving us all needed data and also thanks for all the respondent who can share their experience about self-care, and the last thanks for the academic community of Unika Santu Paulus Ruteng for the circumstance we were provided for this research.

\section{References}

[1] Kemenkes RI. Hari Kusta Sedunia. 1 (2015).

[2] Soedarto 2009.Penyakit-Penyakit Infeksi diIndonesia. Widya Medika. Jakarta.

[3] Subdirektorat Kusta \& Frambusia 2006.Modul Pelatihan Program P2 Kusta Bagi UPK. Depkes RI. Jakarta.

[4] WHO (2016). Weekly Epidemiological Record.No. 35. Switzerland Geneva: WHO. http://apps.who.int/iris/bitstream/handle/10665/249601/WER9135.pdf;jsessionid=BCD712DDE AA30D202BB8BD9920E7DC4F?sequence=1.

[5] Kemenkes, (2017). Data dan Informasi: Profil Kesehatan Indonesia 2016.http://www.depkes.go.id/resources/download/pusdatin/profil-kesehatan-indonesia/ProfilKesehatan-Indonesia-2016.pdf

[6] Hartanti, Rita Dwi, Dkk. (2015). Perawatan diri Pasien Kusta. Jurnal Ilmiam Kesehatan. Vol. VII, No.1, Maret 2015

[7] Potter, P. A, Perry, A.G. Buku Ajar Fundamental Keperawatan: Konsep, Proses, dan Praktik. Edisi 4. Volume 2. Alih Bahasa: Renata Komalasari,dkk. Jakarta: EGC.2005

[8] Bandur, A. (2014). Penelitian Kualitatif. Metode, Desain dan Teknik Analisis Data dengan NVIVO 10. Jakarta: Mitra Wacana Media.

[9] Isro'in,Laily \& Sulistyo Andarmoyo (2012).Konsep Proses dan aplikasi dalam praktik keperawatan.Graha Ilmu. Yogyakarta.

[10] A.Azis Alimul Hidayat \& Musrifatul Uluyah. (2014). Pengantar kebutuhan Dasar Manusia. Edisi 2. Jakarta: Salemba medika.

[11] Tarwanto, Wartonoh (2015) Kebutuhan Dasar Manusia dan Proses Keperawatan Edisi 5. Jakarta Selatan: Salemba Medika

[12] Faruq Umar (2018) Hubungan Tingkat Kecacatan Dengan Perawatan Diri Pada Klien Kusta Di Wilayah Kerja Puskesmas Rowotengah Kabupaten Jember. https://repository.unej.ac.id/handle/123456789/85709

[13] Nursita Mahanani (2013) Faktor-Faktor Yang Berhubungan Dengan Perawatan diri Kusta Penderita Kusta Di Puskesmas Kunduran Kecamatan Kunduran Kabuaten Blora. http://lib.unnes.ac.id/18240/ 